\title{
〔解 説〕
}

\section{建設用ロングアーム作業機の振動抑制制御}

\author{
本間和 男** 中島吉 男** \\ 広島䒠徭満広志***
}

\section{1. は じめに}

土木, 建設業界では, 建設作業, 保守点検作業等の省 力化, 安全化, 高効率化が急務となって招り, 既に各種 機械が開発されている. クレーンに関しては, 鉄筋の配 筋や建設中の建屋内への資材の搬入などの各種建設作業 に対応できる「ロングアームマニピュレータ」を搭載し た移動式作業機が望まれている.

このようなロングアームマニピュレータにおいて, 従 来の産業用ロボットの設計思想である剛性設計を適用す ると, 全体重量が膨大となり, 移動式作業機械として成 り立たなくなる。一方, 強度を優先した軽量化設計を行 らと、アームが柔構造となり,アームのたわみと振動に よる位置決め精度の悪化が問題となる。従って, それを 解決するための振動抑制が必要となる.

そこで, 軽量高剛性化設計技術, 及び柔構造ロングア 一ムの制御技術を開発し, 軽量, 低振動で, かつ分解運 動速度制御の機能を有する操作性の良いロングアームマ

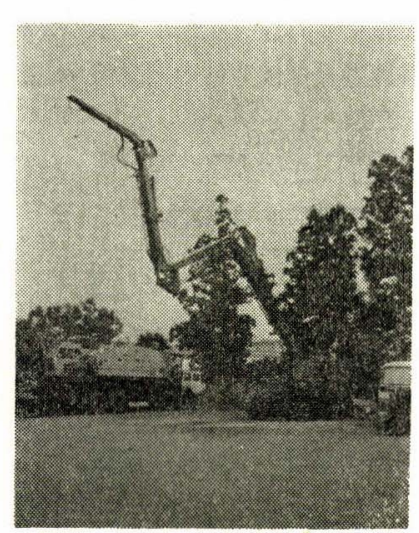

写真 1 移動式作業機の外観 ニピュレータを備党 た移動式作業機を実 現した.

以下，建設用ロン グアーム作業機とそ の振動抑制制御につ いて述べる.

\section{2. 移動式作業 機の概要}

図1, 写真 1 K口 ングアームマニピュ レータを備えた移動

原稿受領 1988 年 8 月 16 日

* Vibration Damping Control of Construction Machine with Long Arm Manipulator

**(株)日立製作所機械研究所

*** 日立建機(株)FAI 工場部
式作業機を示す.この作業機は 4 関節アームと旋回機構, 及びクローラ式移動機構からなって找り，障害物の回り 込及作業や地面下での作業が可能であり, 動作範囲が非 常に広くなっている.さらに, アームの收納性がよいの で，走行体としてトラックを使用することも可能である.

\section{3. 振動抑制制御システム}

\section{1 実験装置の概要}

建設用ロングアーム作業機の開発に当たり, 初めにコ ンクリートデストリビュータを改造した 3 関節の実験機 を用いて基礎的な実験検討を行った。

図 2 亿実験装置の全体システムの概要を示す．この実 験機は, 第 1 アーム, 第 2 アーム, 第 3 アームとそれら を駆動する油压ンリンダから構成されて拈り，アーム全 長は約 $16 \mathrm{~m}$ である. 油压回路は, 油圧制御弁としてサ 一ボ升を用い, 油压シリンダの両ポートにはパイロット チェック弁を備えている.

コントロールコニットには操作レバーからの速度指令 入力信号, 油圧回路の圧力信号, 各アームの相対角度信 号, アーム先端の加速度信号などが入力され，コントロ ールニニットでは, それらの信号を処理して, チェック 升の切り換光信号とサーボ弁の電流信号を出力する.

又, 各アームの主要部分には, 応力測定を目的とし て, 雨ゲージが貼られている.

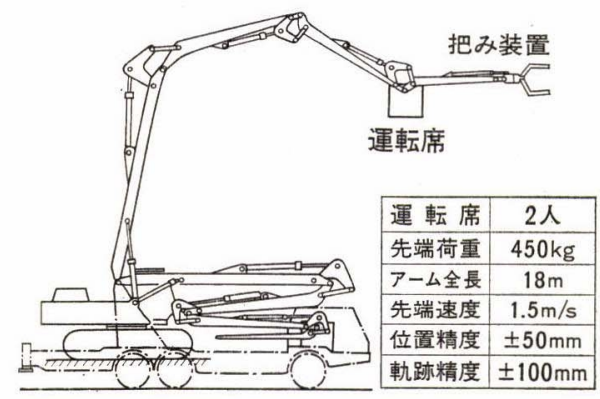

図 1 移動式作業機 


\section{2 振動抑制の方式}

ロングアームマニピュレータの振動を抑制するために は, 次に示す 3 種類の制御が必要である.

（1）圧力マッチング制御：アーム起動時，パイロッ トチェック弁の前後の圧力を一致させる制御.

（2）緩起動, 緩停止制御 : アームの起動, 停止時に 過大な操作加速度の入力を阻止する制御.

（3）振動抑制制御：外乱等, なんらかの原因で振動 が生じたならば, 速やかに振動を減衰させる制御.

\subsection{1 圧力マッチング制御}

操作レバーから, 油圧シリンダを駆動する入力がコン トロールユニットに入ると, パイロットチェック弁を開 くと共にサーボ弁に電流信号を出力するが，そのとき， パイロットチェック弁の前後に大きな圧力差があると高 圧側から低圧側に油が流れることによる切り換えショッ クがでて，アームが振動する，そこで，チェック弁が閉 じた状態でシリンダのロッド側圧力 $P_{r}$ とへッド側圧力 $P_{h}$ を検出し, サーボ弁の両ポート圧力を制御して, チ エック弁前後の圧力差によるシリンダ推力の差を極力小 さくした後，チェック弁を開くそその制御内容をブロッ ク線図で表すと図 3 になる，なお，チェック弁の開閉は 切り換允動作のむだ時間も考慮して行っている.

\subsection{3 緩起動, 緩停止制御}

乱暴に操作レバーを動かした場合, その操作量に比例 してサーボ升の電流を増減すると, 油圧リシンダが急加 速，または急減速して，アームに大きな振動が発生す る. そのようなときでも，アクチュエータの加速及び減 速時に生ずる最大加速度及び最大減速度を制限してやれ ば，ショックなくスムーズに加減速できる，その方法を 次に示す.

アクチュエータに対応したそれぞれのサーボ弁につい

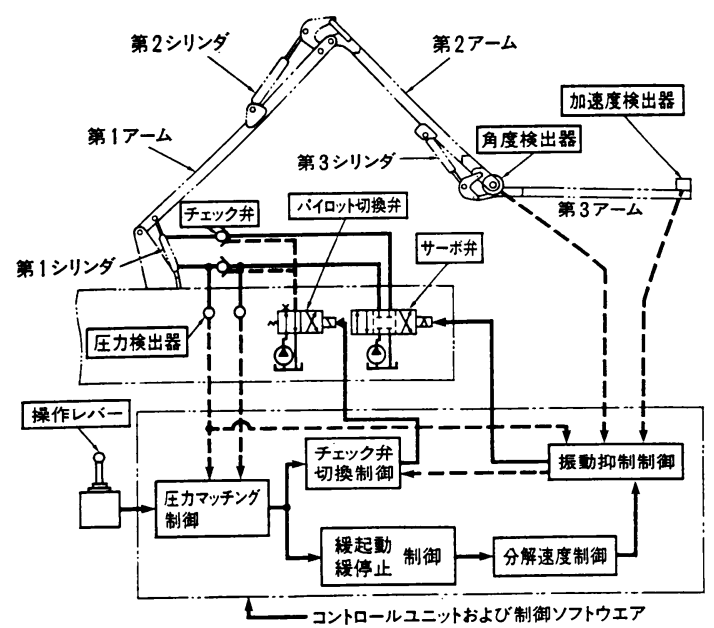

図 2 全体制御システムの概念図

広島 実 稲満広志

て，単位時間当たりの電流增分量の最大值 $\Delta i_{\max }$ を決 めておき, 操作レバーが急激に操作された時には, 電流 増分量の最大值 $\Delta i_{\max }$ で操作し, ゆるやかなレバー操 作のときには, そのレバー操作速度に対応してサーボ弁 の電流值を増減する.

\subsection{4 振動抑制制御}

アームの減衰特性の改善策としては, 油圧回路に絞り 等の抵抗を挿入する方法や, アーム先端の加速度をつィ 一ドバックする方法, アームに多数の雪ゲージを貼り, 応力の分布を検出してフィードバックする力法などが考 兄られる. しかし, 第一の方法は, 油圧回路の変更によ る回路効率の低下があり, 得策ではない. 第二の方法 は, 各アーム間の干渉に対する補償などが必要になり, 制御が難しくなる. 又, 第三の方法は, 正ゲージの信頼 性, 制御の複雑さなどが問題となる.

一方, アームが振動することによって油圧シリンダに 外力が加わり, その反力によって油圧シリンダ内の圧力 が振動する. この変動圧力は加速度とほぼ同等の举動を 示す. 従って, 油压シリンダ内の圧力をフィードハック すればアームの減衰特性が改善される. 但し, 油圧シリ ンダ内の王力をそのままフィードバックしたのではフー ムの剛性が低下するため, 王力の変動分のみ抽出してフ ィードバックする必要がある.

そこで, 油王シリンダ内の圧力に基づいて, 油圧シリ ンダに加わっている変動外力を演算し, その外力が小さ くなるように制御して減衰特性を改善する.图4 にその ブロック線図を示す，同図におけるフィルタは变動圧力 のみを抽出するためのハイパスフィルタである.

\section{3 実験結果}

図 5 に緩起動，緩停止制御の特性を示す. 3 本のアー ムを一直線にし, 最大加速度及び減速度の制限值 $\alpha_{\max }$

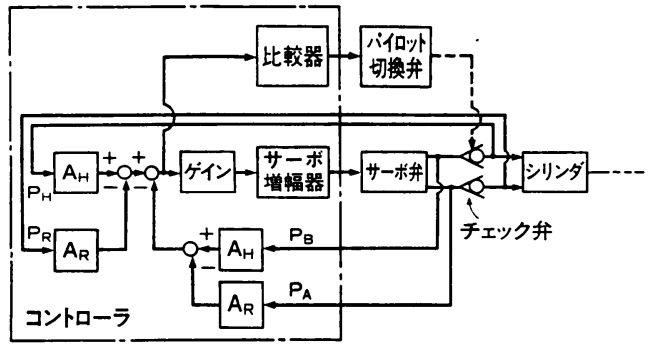

図３王力マッチング制御のブロック線因

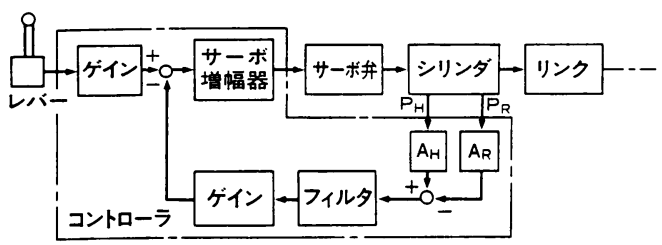

图 4 振動抑制制御のブロック楾図 


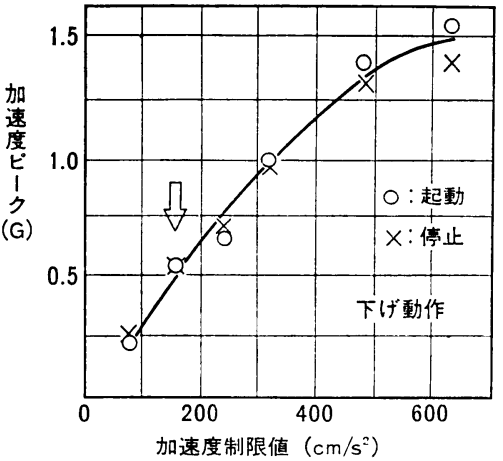

図 5 緩起動, 緩停止制御の特性:

を種々变えて第1 アームを操作したときの, 第 3 アーム 先端の加速度のピーク值を測定したものである.

図 5 から, 制限值 $\alpha_{\max }$ を小さくすれば, 当然, 加速 度ピーク值が小さくなることが分かる，但し，制限值 $\alpha_{\max }$ をあまり小さくすると, 起動, 停止が緩慢にな り, 操作性が悪くなる，そこで，実験により，操作性を 損なわない程度の值, 約 $160 \mathrm{~cm} / \mathrm{s}^{2}$ (図中矢印) 飞決め た.この值を用いると， 3 本のアームを一直線にした最 大速度での下げ動作中に，急激にレバーを戻した時点か ら約 0.7 秒後に, アーム先端が約 $38 \mathrm{~cm}$ 下がって停止 することになるが，位置決め等に特別問題は生じなかっ た.

図 6,7 に振動抑制が無い場合とある場合の実駼結果 の一例を示す. 両図は 3 本のアームを一直線にし，第 1 シリンダを駆動してアームを下げた場合の起動と停止時 そ拈ける各部の挙動を示したものである，その結果，制 御が無い場合は起動, 停止時とも大きな加速度ピークが 生じると共に，非常に振動の減衰が悪いが，制御がある 場合は加速度ピークが小さく，振動が速やかに減衰して いることが分かる．振動抑制を行うことにより，振動抑 制制御が無い場合に比べ，減衰俰数比を 0.06 から 0.31

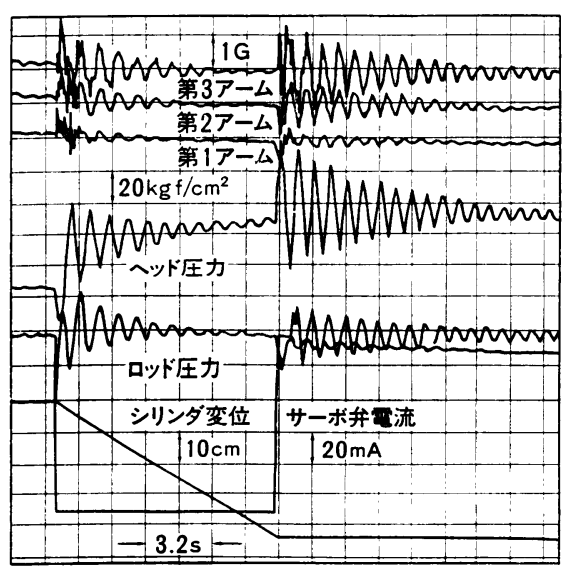

図 6 振動抑制が無い場合の実験結果

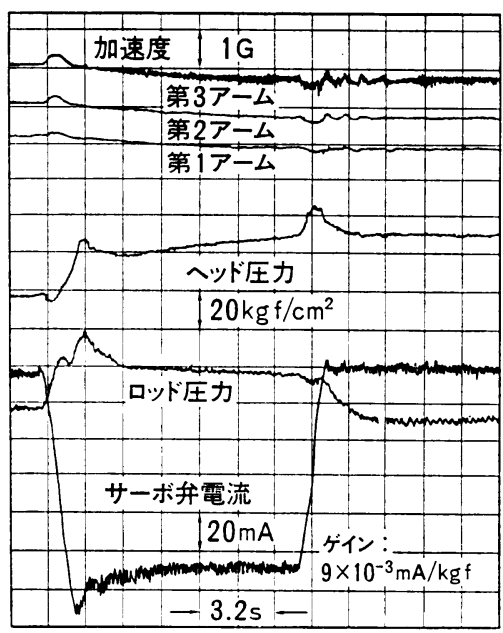

図 7 振動抑制がある場合の実験結果（アーム系）

まで高めることが出来た。

なお，振動抑制制御は各アームそれぞれ独立に構成し たが，アーム間の干渉は特に観察されず，あらゆるアー ム姿勢飞扣いて，良好な制御性能を示した。

図 8 亿振動抑制制御を行った場合と行わない場合のア 一ム最大応力の比較を示す. 振動抑制制御を行らことに より, 振動応力の最大值が約 $1 / 3$ に減少することが確認 された。

\section{4. 分解運動速度制御}

\section{1 制御方式}

多関節マニピュレータを操縦する場合，レバー操作量 と関節速度が対応するように構成すると，アーム先端の 運動が円弧軌跡となるため, 操作性に問題があり，関節 数が多ければ多いほど操作が難しくなる。 そこで，ロン グアーム作業機では分解運動速度制御を用いることにし た.

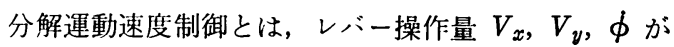

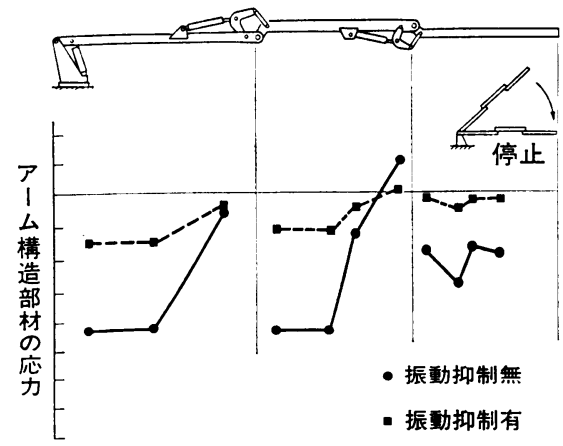

図 8 振動制御による振動応力の減少（実験値） 
第 4 アーム先端の動作速度の直交成分及び第 4 アーム姿 勢角速度にそれぞれ対応するように第 2〜第 4 シリンダ の速度を制御するるのである.なお，第1 フームは半固 定とし, 第 1 アームの姿勢を变えたときでもレバー操作 量と第 4 アーム先端の動作が対応するように構成した.

図 9 に分解運動速度制御の機能プロック線図を示す. レバー操作量 $V_{x}, V_{y}, \dot{\phi}$ ととの時点での関節角度 $\theta_{0}$ から逆座標変換演算により, 各関節の目標角度 $\theta_{r}$ と目 標角速度 $\dot{\theta}_{r}$ を求め, 関節角度をサーボ制御する.サー ボ制御部ではフィードバック制御とフィードフォワード 制御を併用している.なお，各シリンダ間で流量のアン バランスがある場合にはサーボ弁の流量が飽和しアーム 先端の運動軌跡精度が悪化することがある. そこで, 入 力速度指令值からサーボ弁流量を演算し, もし演算結果 が許容值を越えたならば, 分解運動速度の比を維持した ままで, すべてのサーボ弁流量が飽和しないよらに再び 入力值を演算しなおす制御（サーボ弁流量飽和防止制 御）を導入した.

\section{2 実 験 結 果}

図 10 亿実験結果の一例 (水平動作) を示す. その結 果, ストローク約 $8 \mathrm{~m}$ に対して, 移動平均速度約 $40 \mathrm{~cm} / \mathrm{s}$ で軌道精度 $15 \mathrm{~cm}(\mathrm{p}-\mathrm{p})$ を達成した.

\section{5. お わりに}

建設作業のロボット化を進めるためには, 移動機能を 備えたロングアームマニピュレータが不可欠であると考 觉て, 今回の開発を行った. 振動の抑制に関しては, 各 アームの先端加速度を検出してアーム間の干渉を補償す る試みも行ってみたが, 高次の振動モードの干渉まで除 去することが困難であり, 結局, シリンダ内圧の振動成 分をフィードパックするといら最も古典的な方法を採用
することになった，そして，この方法があらゆるアーム 姿勢に対して優れた制御性能を示し, かつ信頼性も高い ことを再確認する結果となった.

本稿が読者諸兄の参考になれば幸いである.

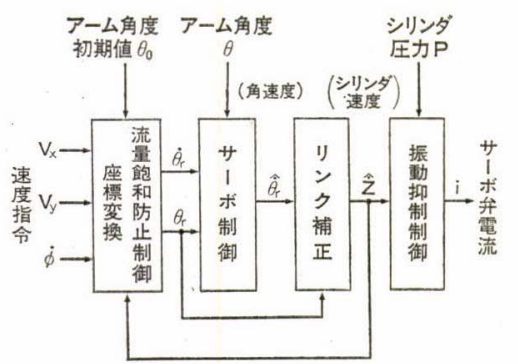

図 9 分解運動速度制御の機能ブロック線図

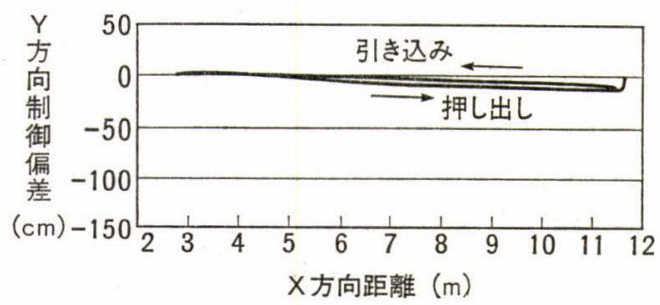

図 10 分解運動速度制御の実験結果の一例（振動抑制, 流量飽和防止有）

\section{参考文 献}

1）森 他, “我社におけるロポットの適用事例”, ロボット, No.38, pp. 62-68 (昭 58-11).

2) 中島 他, “ロンダアームマニピニレータの制御”, 第 5 回日本ロボット学会学術講演会予稿集, pp. 309-310 (昭 62-11).

3）中島 他, “ロングアームマニピニレータの開発”, 第 4 回知能移動ロボットシンポジウム講演予稿集, pp. 187192 (昭 63-6).

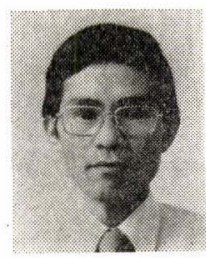

医学会.

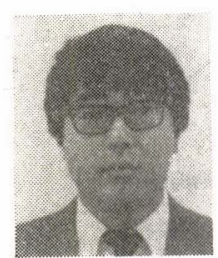

中島吉男 (Kichio NAKAJIMA)

昭和 44 年, 群馬県立伊勢崎工高機械科卒 業, 同年(株)日立製作所機械研究所入所. 建設機械の自動化，ロボット，マニピニレ 一夕の研究開発に従事. 所属学会: 日本口 ボット学会, 日本機械学会.

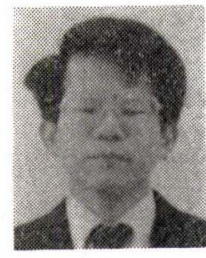

広島 实

(Minoru HIROSHIMA) 昭和46年金沢大学工学部機械工学科卒業, 同年(株) 日立慗作所機械研究所入所. 構造 解析, 構造物の強度と最適化及び多点加振 制御システムを用いた信頼性評価の研究に 従事. 日本機械学会, ターポ 機械協会会 員.

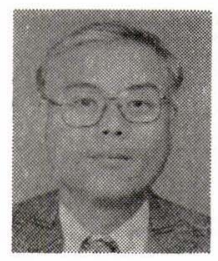

稲満広志 (Hiroshi INAMITSU) 昭和 45 年九州大学工学部採鉱学科卒業. 同年, 日立建機(株)入社. 現在 FA 事業部 開発設計部主任技師. 建設機械, 水処理装 置, 超音波検查装置, ロボットの開発に従 事. 